\title{
ADJUSTMENT SPEED OF DEBT MATURITY: EVIDENCE FROM FINANCIAL CRISES IN EAST ASIA
}

\author{
Hasan Tekin* and Ali Yavuz Polat** \\ *Karabuk University, Karabuk, Turkey. Email: hasantekin@karabuk.edu.tr \\ ** Abdullah Gul University, Kayseri, Turkey. Email: aliyavuz.polat@agu.edu.tr
}

\begin{abstract}
We investigate the change in adjustment speed of debt maturity for East Asian firms between 1990 and 2017 by including two exogenous shocks: the Asian Financial Crisis 1997-1998 (AFC) and the Global Financial Crisis 2007-2009 (GFC). We employ the least square dummy variable correction and find that East Asian firms have a slower adjustment of long-term debt over time. Besides, the decrease in adjustment speed of long-term debt after the GFC is more compared to the decrease after the AFC. Further analysis shows the optimal debt maturity differs across countries and industries. Another important implication of our results is that firms in high governance countries are more likely to close the gap between the actual and target debt maturity in time. Overall, debt holders and investors should consider financial uncertainties.
\end{abstract}

Keywords: Adjustment speed; Asian crisis; Debt maturity; East Asia; Global financial crisis. JEL Classifications: G01; G32.

\author{
Article history: \\ Received : March 03, 2020 \\ Revised : October 30, 2020 \\ Accepted : November 27, 2020 \\ Available online : March 31, 2021 \\ https://doi.org/10.21098/bemp.v24i1.1287
}




\section{INTRODUCTION}

East Asian economies suffered from two significant financial crises in the last decades. The Asian Financial Crisis 1997-1998 (AFC) originated from Thailand and impacted other Asian countries with catastrophic effects on their economies. Then the Global Financial Crisis (GFC) in 2007 spread rapidly across the world as well as the Asian region. Both events provide a unique natural experiment to understand the effect of financial instability on the real economy, especially on the debt maturity structure of firms. This study analyzes how these crises impacted the optimal debt maturity decisions of East Asian firms by providing evidence from both before and after AFC and the GFC.

The East Asian region is unique to study the capital structure and debt maturity choice of firms. The AFC experience had a long-lasting impact on East Asian firms' corporate decisions. After the AFC, there was a regime change in demand function of cash holdings (Song and Lee, 2012), which in turn also may shift leverage and debt maturity choice of East Asian firms. In that sense, East Asian firms are different from firms in developed countries in their cash and leverage policies. Another important advantage of studying East Asian firms is that because they were impacted by the AFC, one can check whether the GFC had a different impact on East Asian firms' debt/leverage decisions.

The optimal debt maturity is a vital decision for firms not only to maximize their value but also to prevent the probability of bankruptcy during financial downturns. The maturity structure is also significantly affected by the availability and terms of credit. During financially distressed times and in its aftermath, information asymmetry forces firms to borrow short term since long term borrowing comes with significant informational costs due to investors willing to lend only for higher premiums in the long term. This makes short-term lending more attractive (Demirgüç-Kunt et al., 2020) and reduces debt maturity. Previous research investigates the association between the financial crisis and optimal debt financing. Zeitun et al. (2017) investigate the effect of GFC on the capital structure of the Gulf Cooperation Council (GCC) countries and show that leverage ratios decrease due to a decrease in lending. They also argue that adjustment speeds of leverage ratios are much slower after the crisis. Tsoy and Heshmati (2019) show that the GFC has a positive effect on the adjustment speed of leverage for Korean firms, unlike the AFC. Compared to earlier literature, this study fills the gap by exploring how financial crises affected East Asian firm's debt maturity choice in a dynamic setting.

We sample firms from eight East Asian countries and employ the Least Squares Dummy Variable Correction (LSDVC) approach. We show that optimal debt maturity shortens over the sample period 1990-2017. Specifically, firms gradually decrease their long-term debt adjustment after the GFC than after the AFC. The reason for this result is probably due to a decrease in credit supply since lending reduced during the GFC (Gonzalez, 2015). Another reason which may intensify the supply-side effect is that firms increase their short-term borrowing since longterm debt becomes expensive during and after a financial crisis creating a demand side effect which decreases long-term borrowing. Our additional results show that the adjustment speed differs across countries and industries. Moreover, we find that governance affects the debt maturity choice. We show that firms operating in 
high governance countries have faster adjustment speeds in all subperiods than those in low governance countries. Similar to our main findings, firms in both high and low governance countries decrease their adjustment speed over time.

The findings from this study make several contributions to the current literature. First, previous research outlines the importance of East Asia and exogenous shocks (Sawicki, 2009; Song and Lee, 2012; Arslan-Ayaydin et al., 2014; Attig et al., 2016). We extend the literature along the lines of optimal debt maturity in the financial crisis context in East Asia. Second, this is the first study to provide evidence that the financial crises shorten optimal debt maturity owing to the shrinkage of credit supply and decreasing demand for long-term credit for East Asian firms. Third, we use a dynamic setting for debt maturity which is an important element to understand the transmission channel of financial crises on the real economy. Fourth, Tsoy and Heshmati (2019) focus on Korean firms' capital structure, our study differs from them by providing an understanding of how the credit supply channel affects firms' optimal debt maturity structure for East Asian firms. Fifth, we believe that our work is the first to show that the governance level affects the adjustment speed of debt maturity for East Asian firms.

\section{OPTIMAL DEBT MATURITY AND FINANCIAL CRISES}

Unlike the Modigliani and Miller (1958) world where there are no frictions, trade-off theory considers the benefits and costs of debt financing (Kraus and Litzenberger, 1973). Debt comes with tax and agency advantages but also includes costs arising from financial distress and agency. Trade-off theory implies that there will be an optimal debt level which balances a dynamic trade-off between the costs and benefits (Fischer et al., 1989). Another indirect implication of trade-off theory is that there will be an optimal debt maturity structure for firms considering lending conditions, informational and agency related costs. Firms may overcome the underinvestment problem and the asset substitution problem to signal their high-quality by issuing short-term debt. ${ }^{1}$

Financial downturns are expected to have a significant effect on both capital structure and term maturity. Alves and Francisco (2015), focusing on 43 countries and in a static setting, show that during financial crisis firms use short-term debt rather than long-term debt. For a sample of 39 countries, Gonzalez (2015) investigates the impact of the global financial crisis on corporate debt maturity. He shows that short-term debt increased more than long-term debt resulting in a reduction in debt maturity. He also finds that the reduction in corporate debt maturity is higher for firms that depend on external finance more heavily.

The literature also focuses on the shortage of credit during a crisis which implies a sharp decrease in lending (Ivashina and Scharfstein, 2010). D'Amato (2020) analyzes the effect of the GFC on the capital structure choice of Italian Small and Medium-sized Enterprises (SMEs). He finds that credit supply shocks reduced Italian SMEs' leverage significantly. They especially decreased their short-term borrowing compared to the period before the crisis. He claims that the short-term borrowing channel is more sensitive to the supply shocks. Duchin et

1 See Ozkan (2000) for a specific discussion of theories related to debt maturity. 
al. (2010) investigate the impact of the 2008 subprime crisis on the US publicly traded firms. Their results show that credit supply channel negatively affected firms' investment and this effect continued even after the crisis due to the demand channel. Campello et al. (2010) survey corporate managers and show that due to the lack of funds during the crisis firms either cancelled or postponed investments.

Zeitun et al. (2017) investigate the effect of the GFC on the capital structure of the GCC countries and show that leverage ratios decrease due to a decrease in lending. Tsoy and Heshmati (2019) focusing only on Korea find that AFC and GFC have a different impact on leverage choices of Korean firms. Analyzing the GCC countries, Mimouni et al. (2019) examine the impact of the GFC on corporate debt maturity and find a negative impact of the GFC on long-term debt. Van Hoang et al. (2018) investigate the effect of the GFC on French micro-enterprises' capital structure. They show that during the GFC micro-enterprises financed themselves mainly through short-term funds to maintain their flexibility. They also claim that the pecking order theory is better in explaining the financial decisions of French micro-enterprises. Demirgüç-Kunt et al. (2020) investigate the capital structure evolution of SMEs, large non-listed and listed companies for the period 2004-2011. They find that firms decrease both their leverage and debt maturity. They claim that the deleveraging is due to a decrease in long-term debt and the effect was more significant in the countries with weaker legal and banking systems. Their results support the view that for publicly listed firms, capital markets provide a "spare tire" in a financial crisis.

Agency costs are important determinants that affect firms' choice of debt maturity (Ozkan, 2002). Short-term debt helps to limit the underinvestment problem (Myers, 1977). In addition, short-term debt mitigates asset substitution problem (Jensen and Meckling, 1976), since the firm needs to pay back its debt before any risky growth opportunity to be exercised (Barnea et al., 1980; Leland and Thoft, 1996). During a financial crisis uncertainty and cash flow volatility increases (Lozano and Yaman, 2020), which in turn make the asset substitution problem more severe resulting in increased agency costs. Thus, considering the moral hazard incentives of a borrower, lenders are reluctant to lend long-term in a high uncertainty environment. Also considering that during financial downturns firms face problems in accessing external finance, firms are expected to care less about reaching their target maturity after a crisis so that speed of adjustment may decrease. Another important impact of the crisis is that due to increasing funding costs arising from informational issues, firms are reluctant to borrow long-term in the aftermath of a crisis (Bae and Goyal, 2009; Demirgüç-Kunt et al., 2020). Rather, they prefer short-term debt which implies a decrease in debt maturity.

To the best of our knowledge, none of the earlier studies in the literature focus specifically on the AFC and the GFC for the East Asian region in a dynamic setting in order to understand the effect of both crises on debt maturity structure. In this study, we investigate the effect of both the AFC and the GFC on the adjustment speed of debt maturity. Our main focus is to analyze the following questions: (i) What is the effect of these two crises in the long-run on the adjustment of debt maturity?; (ii) is the speed of adjustment across countries and industries heterogenous?; and iii) does the governance quality influence the adjustment speed of debt maturity. 


\section{METHODOLOGY}

We use the Speed of Adjustment (SOA) model on optimal debt maturity in line with the literature (Ozkan, 2000; Flannery and Rangan, 2006; Gonzalez, 2015; Zeitun et al., 2017; Dang et al., 2019). We state the basic SOA model of debt maturity below:

$$
\mathrm{DM}_{i, t}-\mathrm{DM}_{i, t-1}=\lambda_{i}\left(\mathrm{DM}_{i t^{*}}-\mathrm{DM}_{i, t-1}\right)+\varepsilon_{i, t}
$$

where $\mathrm{DM}_{i, t}$ is the long-term debt to total debt of firm $i$ at time $t, \lambda_{i}$ is the adjustment parameter, and $\varepsilon_{i, t}$ is the time-varying disturbance term.

$$
\mathrm{DM}_{i t^{*}}=\beta \mathrm{X}_{i, t-1}
$$

where $\mathrm{DM}_{i, t}{ }^{*}$ is a target debt maturity ratio, $\beta$ is a coefficient vector and $X_{i, t-1}$ is a vector of firm characteristics considering the costs and benefits of debt maturity at time $t-1$.

After the substitution and rearrangement of Equations (1) and (2), the dynamic SOA model is as follows:

$$
\mathrm{DM}_{i, t}=\left(1-\lambda_{i}\right) \mathrm{DM}_{i, t-1}+(\lambda \beta) \mathrm{X}_{i, t-1}+\alpha_{i} F_{i}+\alpha_{t} Y_{t}+\varepsilon_{i, t}
$$

where $\lambda$ is the adjustment speed. below:

We test our hypotheses using the full dynamic SOA model of debt maturity

$$
\begin{aligned}
\mathrm{DM}_{i, t}= & \left(1-\lambda_{i}\right) \mathrm{DM}_{i, t-1}+(\lambda \beta)[\mathrm{SIZE}+\mathrm{MBR}+\mathrm{PROF}+\mathrm{TAN}+\mathrm{DIV}+ \\
& \mathrm{CASH}]_{i, t-1}+\alpha_{i} F_{i}+\alpha_{t} Y_{t}+\varepsilon_{i, t}
\end{aligned}
$$

where, $\mathrm{DM}_{i, t}$ and $\mathrm{DM}_{i, t-1}$ are long-term debt to total debt for firm $i$ at time $t$ and $t-1$, respectively. Also, the model includes six more firm-level characteristics: firm size (SIZE), the market-to-book ratio (MBR), profitability (PROF), tangibility (TAN), dividends (DIV) and cash holdings (CASH) for firm $i$ at time $t-1$. We use their one year lagged to reduce any simultaneity bias (D'Amato, 2020). Finally, $\alpha_{i} F_{i}$ and $\alpha_{t} Y_{t}$ are firm- and year-fixed effects, respectively, controlling for unobservable factors which affect the debt maturity ratio, and $\varepsilon_{i, t}$ is the error term. All variables are defined in Table 1. 
Table 1.

Variable Definitions

\begin{tabular}{|c|c|c|}
\hline Variables & Definitions & Sources \\
\hline$\overline{D M_{t}}$ & Long-term debt / total debt & Worldscope \\
\hline$D M_{t-1}$ & Lagged [long-term debt / total debt] & Worldscope \\
\hline $\operatorname{SIZE}_{t-1}$ & Lagged [the annual logarithm of total assets] & Worldscope \\
\hline$M B R_{t-1}$ & $\begin{array}{l}\text { Lagged [(total assets - the book value of equity + the market value of equity) } \\
\qquad / \text { total assets }]\end{array}$ & Worldscope \\
\hline PROF ${ }_{t-1}$ & Lagged [EBIT / total assets] & Worldscope \\
\hline $\operatorname{TAN}_{t-1}$ & Lagged [net tangible assets / total assets] & Worldscope \\
\hline$D I V_{t-1}$ & Lagged [cash dividends paid / total assets] & Worldscope \\
\hline $\mathrm{CASH}_{t-1}$ & Lagged [cash and short-term investments/ total assets] & Worldscope \\
\hline$G O V_{t}$ & $\begin{array}{l}\text { Average of Worldwide Governance Indicators (control of corruption, rule of } \\
\text { law, regulatory quality, voice and accountability, politic stability, government } \\
\text { effectiveness) }\end{array}$ & $\begin{array}{l}\text { Kaufmann } \\
\text { et al., (2011) }\end{array}$ \\
\hline $1990-1996$ & Dummy variable equals one for years 1990-1996, otherwise zero & \\
\hline 1999-2006 & Dummy variable equals one for years 1999-2006, otherwise zero & \\
\hline 2010-2017 & Dummy variable equals one for years $2010-2017$, otherwise zero & \\
\hline
\end{tabular}

We estimate the SOA of debt maturity using the LSDVC as Flannery and Hankins (2013) and Dang et al. (2015) suggest. They find that instrumental variables or bias-corrected estimators give correct results compared to Pooled ordinary least squares (OLS) and fixed effects (FE), which are traditional panel data methods. While the system general methods of moments (GMM) of Blundell and Bond (1998) may mitigate the finite sample bias, the LSDVC overcomes the bias; that is why the LSDVC is more appropriate than the system GMM (Dang et al., 2015; Tekin, 2020a, 2020b).

\section{DATA}

We retrieve the firm-level data from Worldscope in Datastream. Since East Asian countries have faced two financial crises in the last two decades, we analyze firms in eight East Asian countries. Using 101,932 firm-years representing 7,626 firms in Hong Kong, Indonesia, Malaysia, the Philippines, Singapore, South Korea, Taiwan and Thailand ${ }^{2}$ for the period 1990-2017, we examine the dynamic debt maturity of East Asian firms excluding the crises periods ${ }^{3}$ : (i) 1997-1998 for the AFC and (ii) 2007-2009 for the GFC.

We focus on non-financial firms by eliminating financial and utility firms because of their different accounting structure (Tekin, 2020b). We keep firms that have a minimum of four consecutive years of data in each subperiod to provide the consistency for our estimations (Coldbeck and Ozkan, 2018). The sample distribution across country and industry is shown in Table 2 .

2 We select eight Asian countries that have been most affected by the Asian crisis 1997-1998, as Song and Lee (2012: 618) argue.

3 Since our interest is in analyzing optimal debt maturity before and after turbulence, we exclude both crisis periods from the entire sample (Tekin, 2020b). 
Table 2.

Sample Distribution Across Country and Industry

\begin{tabular}{lccccccc}
\hline Country & \# firms & \# N & \% N & Industry & \# firms & \# N & \% N \\
\hline 1 Hong Kong & 1,501 & 18,134 & 17.8 & 1 Basic Materials & 829 & 12,212 & 12.0 \\
2 Indonesia & 389 & 5,600 & 5.5 & 2 Consumer Goods & 1,614 & 22,620 & 22.2 \\
3 Malaysia & 804 & 12,184 & 12.0 & 3 Consumer Services & 859 & 11,410 & 11.2 \\
4 Philippines & 150 & 2,484 & 2.4 & 4 Healthcare & 421 & 4,699 & 4.6 \\
5 Singapore & 661 & 9,187 & 9.0 & 5 Industrials & 2,483 & 32,662 & 32.0 \\
6 South Korea & 1,877 & 23,838 & 23.4 & 6 Oil \& Gas & 185 & 2,374 & 2.3 \\
7 Taiwan & 1,670 & 21,983 & 21.6 & 7 Technology & 1,179 & 15,064 & 14.8 \\
8 Thailand & 574 & 8,522 & 8.4 & 8 Telecommunications & 56 & 891 & 0.9 \\
TOTAL & 7,626 & 101,932 & 100.0 & TOTAL & 7,626 & 101,932 & 100.0 \\
\hline
\end{tabular}

Source. Worldscope

We also use lagged firm-level explanatory variables to overcome any endogeneity bias (D'Amato, 2020). Our firm-level control variables are firm size (Ozkan, 2002), market-to-book ratio (Gonzalez, 2015), profitability (Mimouni et al., 2019), tangibility (Fan et al., 2012), cash holdings (Brick and Liao, 2017) and dividends (Vermoesen et al., 2013). Besides, we also control the country-level by employing the governance (Turk Ariss, 2016) due to country-level heterogeneity in our sample.

We winsorize all control variables at the top and bottom 1\% (Tekin and Polat, 2020a, 2020b). We present descriptive statistics and correlation matrix for three subperiods in Table 3 and Table 4, respectively. In Table 4, we report the variance inflation factor (VIF) that indicates whether the explanatory variables face any multicollinearity problem. Specifically, since the maximum VIF value is 1.36 , our data do not suffer from multicollinearity (Freund et al., 2006).

Table 3.

Descriptive Statistics

\begin{tabular}{lccccccccc}
\hline & & $D_{t}$ & SIZE $_{t-1}$ & MBR $_{t-1}$ & PROF $_{t-1}$ & TAN $_{t-1}$ & DIV $_{t-1}$ & CASH $_{t-1}$ & $G O_{t}$ \\
\hline Panel A. 1990-1996 & Mean & 0.364 & 15.712 & 1.638 & 0.096 & 0.494 & 0.041 & 0.117 & 0.530 \\
& SD & 0.301 & 3.042 & 0.974 & 0.070 & 0.203 & 0.137 & 0.131 & 0.539 \\
& Min & 0.000 & 8.884 & 0.739 & -0.047 & 0.091 & 0.000 & 0.000 & -0.694 \\
& Median & 0.343 & 15.068 & 1.311 & 0.085 & 0.493 & 0.013 & 0.072 & 0.556 \\
& Max & 1.000 & 23.557 & 7.650 & 0.453 & 0.888 & 1.000 & 1.000 & 1.462 \\
Panel B. 1999-2006 & Mean & 0.321 & 15.076 & 1.327 & 0.056 & 0.520 & 0.040 & 0.157 & 0.708 \\
& SD & 0.321 & 3.109 & 1.126 & 0.141 & 0.228 & 0.158 & 0.157 & 0.579 \\
& Min & 0.000 & 4.844 & 0.543 & -0.528 & 0.015 & 0.000 & 0.000 & -0.943 \\
& Median & 0.235 & 14.509 & 1.012 & 0.064 & 0.525 & 0.001 & 0.108 & 0.776 \\
& Max & 1.000 & 25.027 & 14.888 & 0.760 & 0.920 & 1.000 & 1.000 & 1.520 \\
& Mean & 0.294 & 15.637 & 1.531 & 0.043 & 0.556 & 0.029 & 0.201 & 0.817 \\
& SD & 0.321 & 3.124 & 1.559 & 0.145 & 0.215 & 0.104 & 0.178 & 0.588 \\
& Min & 0.000 & 4.605 & 0.539 & -0.847 & 0.118 & 0.000 & 0.000 & -0.539 \\
& Median & 0.174 & 15.096 & 1.093 & 0.054 & 0.559 & 0.004 & 0.150 & 0.823 \\
& Max & 1.000 & 26.284 & 18.902 & 0.571 & 0.933 & 1.000 & 1.000 & 1.615 \\
\hline
\end{tabular}


Table 4.

\section{Correlation Matrix}

\begin{tabular}{lccccccccc}
\hline & & DM $_{t}$ & (1) & (2) & (3) & (4) & (5) & (6) & VIF \\
\hline Panel A. 1990-1996 & (1) $S I Z E_{t-1}$ & 0.210 & & & & & & & 1.62 \\
& (2) $M B R_{t-1}$ & 0.002 & -0.277 & & & & & & 1.39 \\
& (3) $P R O F_{t-1}$ & -0.004 & 0.053 & 0.429 & & & & & 1.37 \\
& (4) $T A N_{t-1}$ & -0.132 & -0.378 & 0.223 & 0.169 & & & & 1.26 \\
& ${\text { (5) } D I V_{t-1}}$ & -0.024 & -0.037 & 0.080 & 0.104 & 0.061 & & & 1.04 \\
& (6) $C A S H_{t-1}$ & 0.037 & -0.023 & 0.130 & 0.191 & 0.189 & 0.186 & & 1.11 \\
& (7) $G O V_{t}$ & 0.035 & -0.448 & 0.011 & -0.200 & 0.070 & -0.024 & 0.042 & 1.33 \\
Panel B. 1999-2006 & (1) $S I Z E_{t-1}$ & 0.173 & & & & & & & 1.36 \\
& (2) $M B R_{t-1}$ & -0.011 & -0.191 & & & & & & 1.14 \\
& (3) $P R O F_{t-1}$ & 0.025 & 0.159 & -0.022 & & & & & 1.12 \\
& (4) $T A N_{t-1}$ & -0.202 & -0.233 & -0.007 & 0.236 & & & & 1.30 \\
& (5) $D I V_{t-1}$ & -0.020 & 0.036 & 0.048 & 0.072 & 0.028 & & & 1.01 \\
& (6) $C A S H_{t-1}$ & -0.137 & -0.152 & 0.273 & 0.108 & 0.351 & 0.057 & & 1.28 \\
& (7) $G O V_{t}$ & -0.024 & -0.413 & 0.089 & -0.089 & 0.119 & 0.018 & 0.197 & 1.24 \\
Panel C. 2010-2017 & (1) $S I Z E_{t-1}$ & 0.107 & & & & & & & 1.21 \\
& (2) $M B R_{t-1}$ & -0.014 & -0.118 & & & & & & 1.10 \\
& (3) $P R O F_{t-1}$ & 0.009 & 0.165 & -0.052 & & & & & 1.13 \\
& (4) $T A N_{t-1}$ & -0.193 & -0.224 & 0.029 & 0.166 & & & & 1.29 \\
& (5) $D I V_{t-1}$ & -0.021 & -0.075 & 0.139 & 0.171 & 0.097 & & & 1.07 \\
& (6) $C A S H_{t-1}$ & -0.160 & -0.199 & 0.237 & 0.087 & 0.401 & 0.115 & & 1.36 \\
& (7) $G O V_{t}$ & -0.044 & -0.278 & -0.007 & -0.132 & 0.025 & -0.022 & 0.222 & 1.16 \\
\hline
\end{tabular}

Source. Worldscope / Kaufmann et al. (2011)

\section{MAIN RESULTS}

We compare the SOA of debt maturity of firms in East Asia from 1990 through 2017 by dividing the sample into subperiods to understand the variation in SOA of debt maturity. We report results in Table 5.

Table 5.

\section{Adjustment Speed of Debt Maturity Before and After Financial Crises}

This table shows the Least Square Dummy Variable Correction (LSDVC) regression estimates the adjustment speed of long-term debt - the lagged long-term debt by controlling firm-level variables. The dependent variable is long-term debt - DM. Adjusted standard-errors are reported in parentheses (.).******, and *imply significance at the $1 \%, 5 \%$ and $10 \%$.

\begin{tabular}{lccc}
\hline & \multicolumn{3}{c}{ Dependent variable: $D M_{+}$} \\
\hline$D M_{t-1}$ & $\mathbf{1 9 9 0 - 1 9 9 6}$ & $\mathbf{1 9 9 9 - 2 0 0 6}$ & $\mathbf{2 0 1 0 - 2 0 1 7}$ \\
& $0.392^{* * * *}$ & $0.416^{* * *}$ & $0.455^{* * *}$ \\
Controls & $(0.001)$ & $(0.004)$ & $(0.004)$ \\
SIZE & & & \\
& 0.019 & 0.006 & $0.024^{* * *}$ \\
$M B R_{t-1}$ & $(0.023)$ & $(0.010)$ & $(0.001)$ \\
& $0.023^{*}$ & $0.007^{* * *}$ & $0.006^{* *}$ \\
& $(0.012)$ & $(0.001)$ & $(0.003)$ \\
\hline
\end{tabular}


Table 5.

Adjustment Speed of Debt Maturity Before and After Financial Crises (Continued)

\begin{tabular}{lccc}
\hline & \multicolumn{3}{c}{ Dependent variable: $\mathbf{D M _ { t }}$} \\
\hline PROF \\
& $\mathbf{1 9 9 0 - 1 9 9 6}$ & $\mathbf{1 9 9 9 - 2 0 0 6}$ & $\mathbf{2 0 1 0 - 2 0 1 7}$ \\
& $-0.315^{* * *}$ & 0.039 & $-0.019^{* * *}$ \\
TAN $_{t-1}$ & $(0.084)$ & $(0.067)$ & $(0.001)$ \\
& 0.026 & $-0.092^{* * *}$ & 0.010 \\
DIV & $(0.028)$ & $(0.029)$ & $(0.019)$ \\
& $0.066^{* * *}$ & -0.024 & 0.012 \\
& $(0.025)$ & $(0.018)$ & $(0.021)$ \\
CASH $_{t-1}$ & -0.029 & $-0.095^{* * *}$ & $-0.034^{* * *}$ \\
& $(0.086)$ & $(0.016)$ & $(0.001)$ \\
GOV & & $0.044^{*}$ & $-0.010^{* * *}$ \\
& & $(0.026)$ & $(0.000)$ \\
Firm FE & $\checkmark$ & $\checkmark$ & $\checkmark$ \\
Year FE & $\checkmark$ & $\checkmark$ & $\checkmark$ \\
\# of firms & 914 & 4,401 & 7,153 \\
\# of observations & 2,940 & 22,110 & 47,154 \\
\hline
\end{tabular}

The mean long-term debt decreases over time, as shown in Table 3. Similarly, the SOA of long-term debt decreases as presented in Table 5. Specifically, the coefficient of lagged long-term debt is 0.392. In other words, East Asian firms close the gap between actual and target debt maturity with $60.8 \%$ SOA, which is calculated as one minus the coefficient of lagged long-term debt.

In the aftermath of the AFC (1999-2006), the supply of credit decreases. This results with a fall in SOA of long-term debt. The SOA of debt maturity decreases by $2.4 \%$ from pre- to post-AFC as shown in column II (the coefficient of lagged long-term debt becomes 0.416).

Finally, from 2010 to 2017, the SOA of long-term debt drops from $58.4 \%$ to $54.5 \%$ after the GFC (column III). Interestingly, the decrease in SOA of long-term debt after the GFC is $1.5 \%$ more compared to that after AFC. This may occur due to the severity of the GFC compared to the AFC and the shrinkage of credit supply. For example, Zeitun et al. (2017) examine the SOA of leverage for firms in the GCC countries before and after the GFC. They show that firms in GCC countries decrease their target leverage after the financial crisis because of decreasing credit supply. Moreover, firms are reluctant to borrow long-term during the GFC since it was too costly to get long-term debt due to informational issues (Campello et al., 2010; Duchin et al., 2010). This, in turn, reduced long-term borrowing.

Regarding firm-level control variables, the coefficient and sign fluctuate across subperiods. Specifically, the positive relationship between firm size and debt maturity becomes significant in the last subperiod. Long-term debt is important for larger firms between 2010 and 2017 (Demirgüç-Kunt et al., 2020). This maybe due to increasing agency costs after the crisis which makes it harder to find long term debt at fair interest levels (Gürkaynak and Wright, 2012). Besides, the negative significance of market-to-book on long-term debt rise and fall. In other words, firms 
with high growth opportunities increase their long-term debt more in the 19992006 period than in 2010-2017. Furthermore, firms with low profitability increase their long-term debt before 1999 and after 2006, but those with low tangibility rise it during 1999-2006. Interestingly, the dividend payment has only impacted debt maturity before the AFC, and cash holdings became significant after the AFC due to the transaction motive.

\section{ADDITIONAL RESULTS}

We do further analyses to understand how optimal debt maturity differs across (i) countries, (ii) industries, and (iii) governance for the subperiods: 1990-1996, 1999-2006 and 2010-2017. Before regression analyses, we present the trend of debt maturity between 1990 and 2017 for each country, industry, and governance level in our sample by Figure 1, Figure 2, and Figure 3, respectively. For brevity, we report only the coefficients of lagged long-term debt in Tables 6 and 7.

Figure 1.

Trend of Debt Maturity Across Countries

This figure presents the trend of debt maturity across eight East Asian countries from 1990 to 2017.

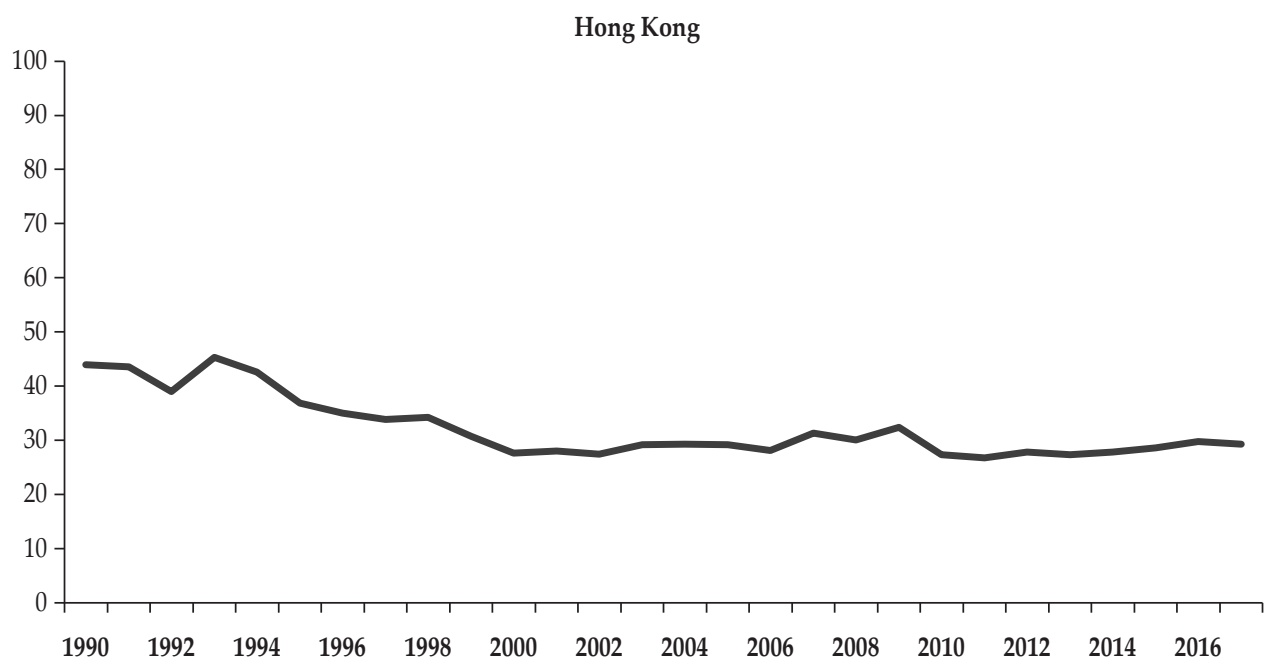


Figure 1.

Trend of Debt Maturity Across Countries (Continued)
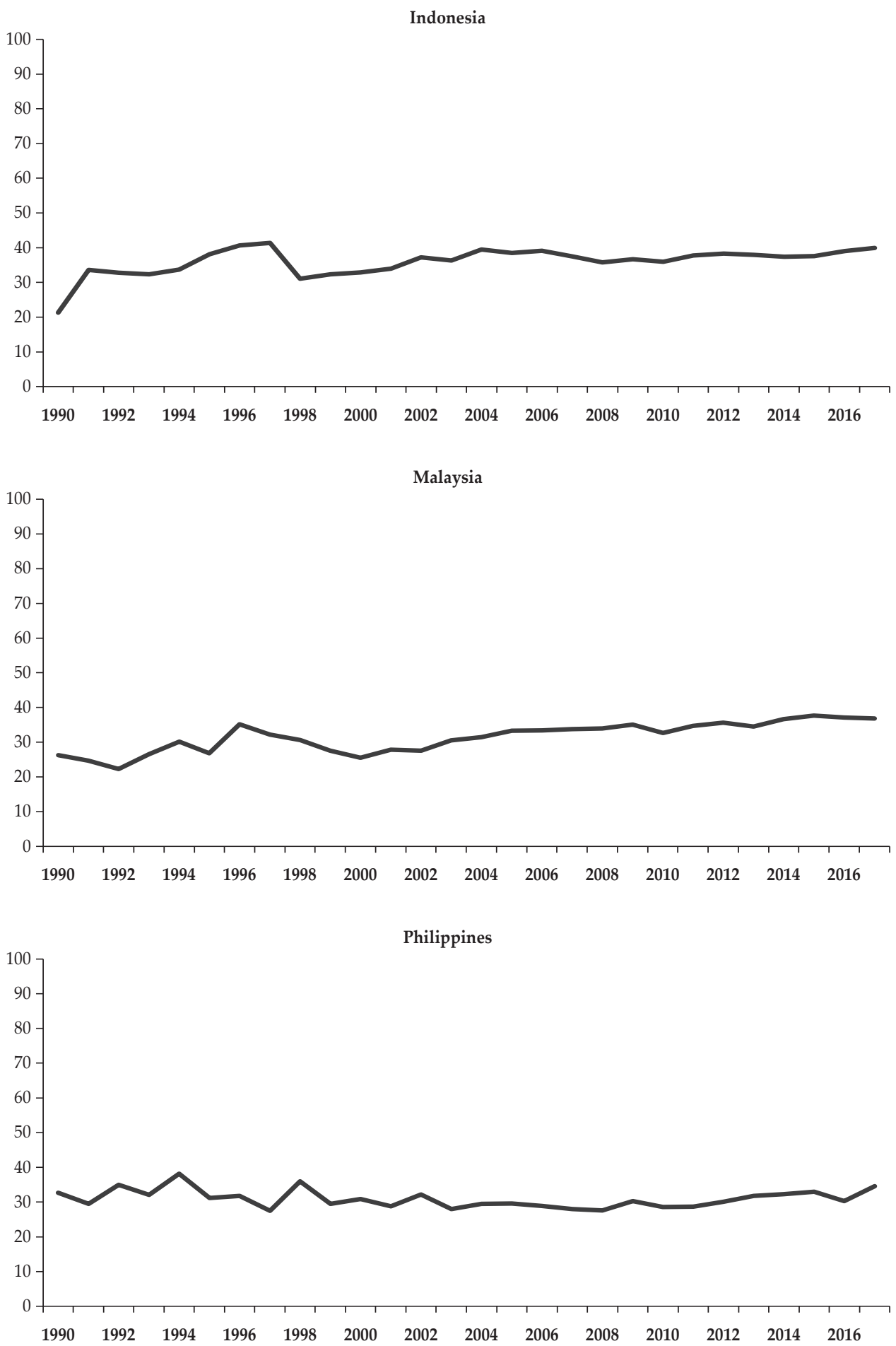
Figure 1.

Trend of Debt Maturity Across Countries (Continued)
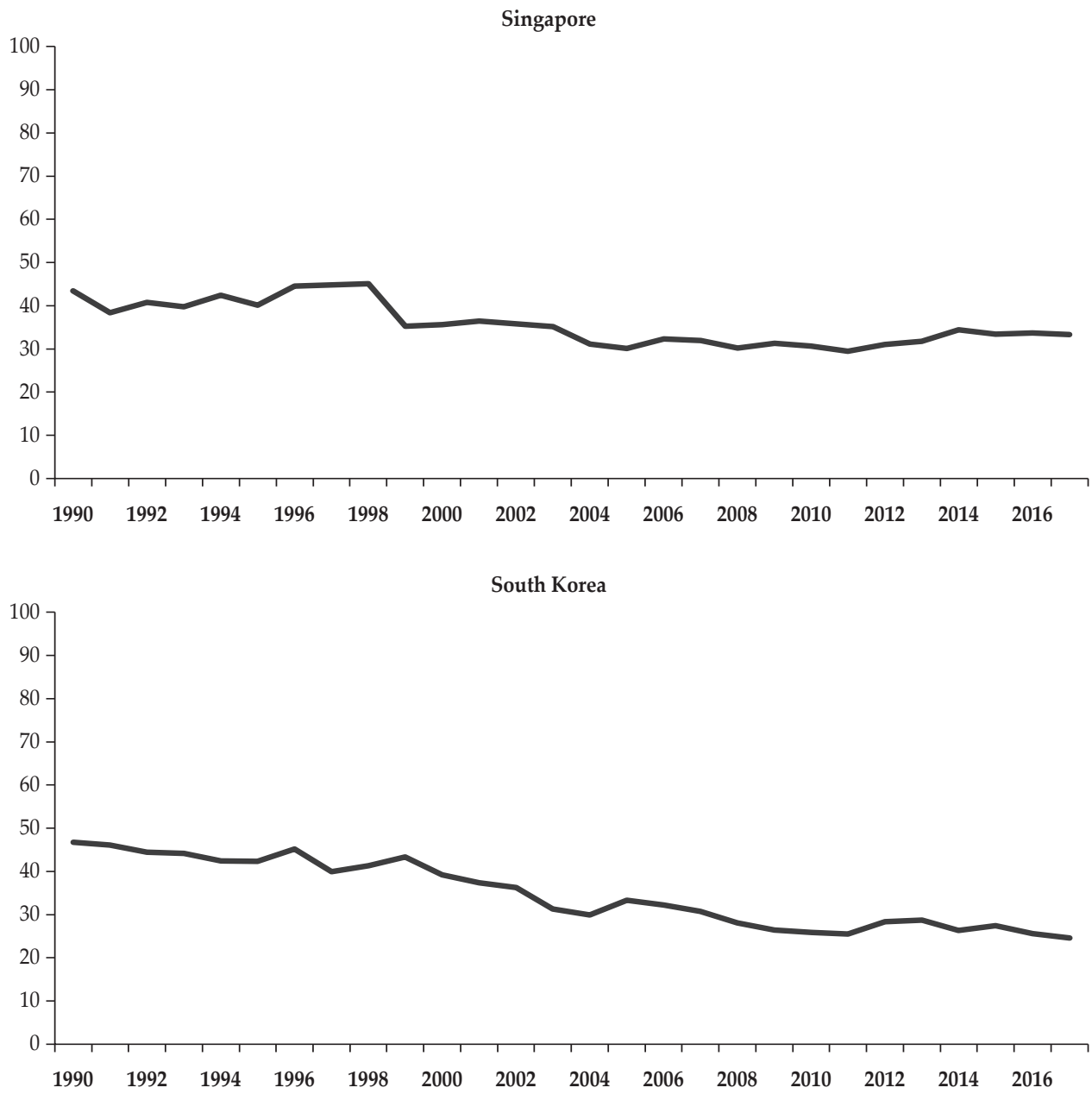

Taiwan

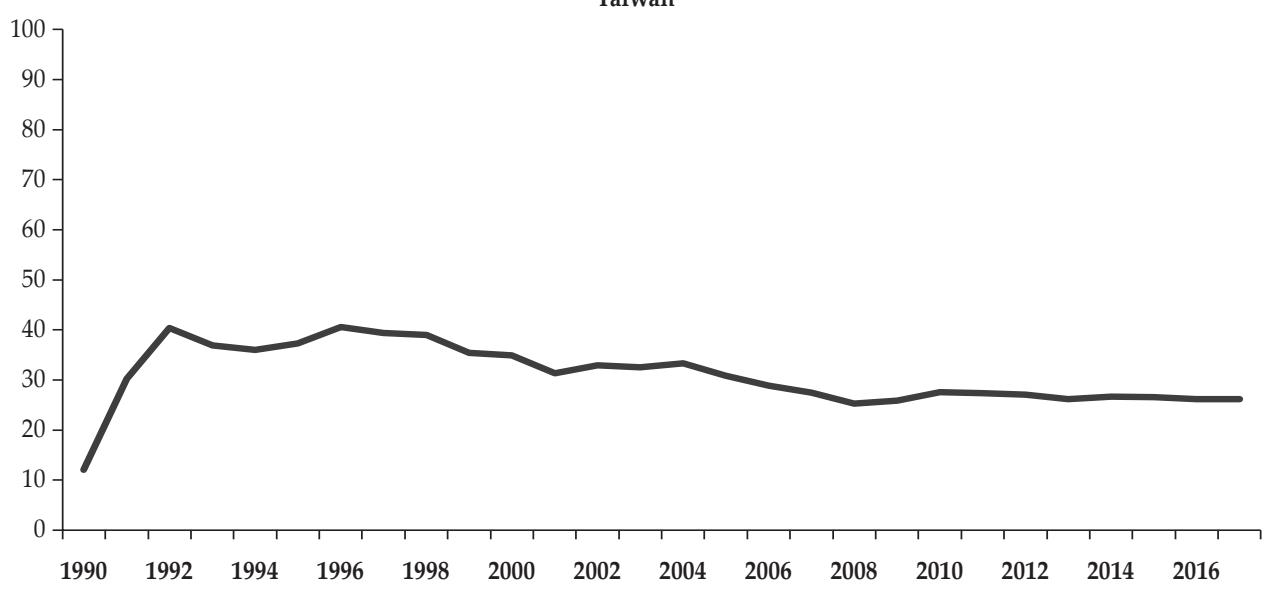


Figure 1.

Trend of Debt Maturity Across Countries (Continued)

Thailand

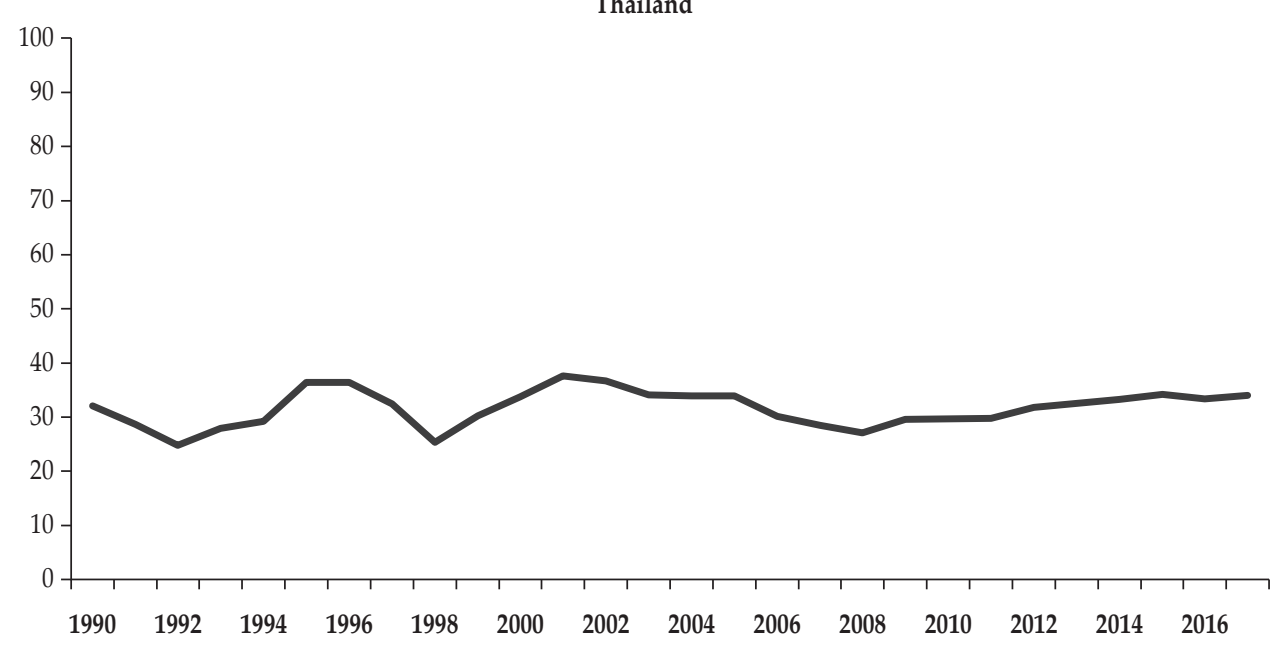

Source: Worldscope

Table 6.

Adjustment Speed of Debt Maturity by Country

This table shows the adjustment speed of long-term debt - the lagged long-term debt using the LSDVC across eight East Asian countries. The dependent variable is long-term debt - DM. Adjusted standard-errors are reported in parentheses (.). Observation numbers are reported italic in brackets [.].*** indicates significance at $1 \%$.

\begin{tabular}{lccccccc}
\hline \multicolumn{7}{c}{ Dependent variable: $D M_{+}$} \\
\hline Country & $1990-1996$ & $1999-2006$ & $\mathbf{2 0 1 0 - 2 0 1 7}$ & Country & $\mathbf{1 9 9 0 - 1 9 9 6}$ & $\mathbf{1 9 9 9 - 2 0 0 6}$ & $\mathbf{2 0 1 0 -}$ \\
\hline Hong Kong & $0.435^{* * *}$ & $0.419^{* * *}$ & $0.445^{* * *}$ & Singapore & $0.295^{* * *}$ & $0.371^{* * *}$ & $0.504^{* * *}$ \\
& $(0.055)$ & $(0.005)$ & $(0.001)$ & & $(0.099)$ & $(0.018)$ & $(0.011)$ \\
& {$[447]$} & {$[3,920]$} & {$[7,921]$} & & {$[277]$} & {$[1,996]$} & {$[4,156]$} \\
Indonesia & $0.373^{* * *}$ & $0.574^{* * *}$ & $0.529^{* * *}$ & South Korea & $0.422^{* * *}$ & $0.319^{* * * *}$ & $0.384^{* * *}$ \\
& $(0.127)$ & $(0.021)$ & $(0.037)$ & & $(0.002)$ & $(0.004)$ & $(0.012)$ \\
& {$[310]$} & {$[1,352]$} & {$[2,335]$} & & {$[522]$} & {$[4,663]$} & {$[12,358]$} \\
Malaysia & $0.387^{* * *}$ & $0.593^{* * *}$ & $0.614^{* * *}$ & Taiwan & $0.519^{* * *}$ & $0.287^{* * *}$ & $0.418^{* * *}$ \\
& $(0.002)$ & $(0.027)$ & $(0.002)$ & & $(0.067)$ & $(0.007)$ & $(0.002)$ \\
& {$[517]$} & {$[3,104]$} & {$[5,428]$} & & {$[263]$} & {$[4,533]$} & {$[10,643]$} \\
Philippines & $0.589^{* * *}$ & $0.555^{* * *}$ & $0.517^{* * *}$ & Thailand & $0.536^{* * *}$ & $0.493^{* * *}$ & $0.513^{* * *}$ \\
& $(0.043)$ & $(0.025)$ & $(0.024)$ & & $(0.041)$ & $(0.035)$ & $(0.013)$ \\
& {$[120]$} & {$[628]$} & {$[948]$} & & {$[484]$} & {$[1,914]$} & {$[3,365]$} \\
Controls & $\checkmark$ & $\checkmark$ & $\checkmark$ & Controls & $\checkmark$ & $\checkmark$ & $\checkmark$ \\
Firm FE & $\checkmark$ & $\checkmark$ & $\checkmark$ & Firm FE & $\checkmark$ & $\checkmark$ & $\checkmark$ \\
Year FE & $\checkmark$ & $\checkmark$ & $\checkmark$ & Year FE & $\checkmark$ & $\checkmark$ & $\checkmark$ \\
\hline
\end{tabular}

In Table 6, we repeat our analyses for each country: Hong Kong, Indonesia, Malaysia, the Philippines, Singapore, South Korea, Taiwan and Thailand. While 
the Philippines firms increase their target long-term debt level, firms in Malaysia and Singapore decrease their target long-term debt over time. Besides, Indonesian firms drop and raise their target long-term debt from 1990 to 2017, but it is the opposite for firms in Hong Kong, South Korea, Taiwan and Thailand. In period 1990-1996, the Philippine and Singapore firms close the gap between actual and target long term debt with $41.1 \%$ as the slowest SOA and $70.5 \%$ as the fastest SOA, respectively. Then, the Asian 1997-1998 crisis occurred, and companies changed their debt maturity policies due to rising costs of accessing external finance and increasing costs of long-term borrowing. After the Asian crisis, firms in Malaysia and Taiwan have the slowest and fastest SOA of long-term debt with $40.7 \%$ and $71.3 \%$ in that order during 1999-2006. Lastly, Malay and South Korean firms have the slowest and fastest SOA of long-term debt with $38.6 \%$ and $61.6 \%$, respectively, in the period 2010-2017.

Figure 2.

Trend of Debt Maturity Across Industries

This figure presents the trend of debt maturity across industries from 1990 to 2017 in East Asia.

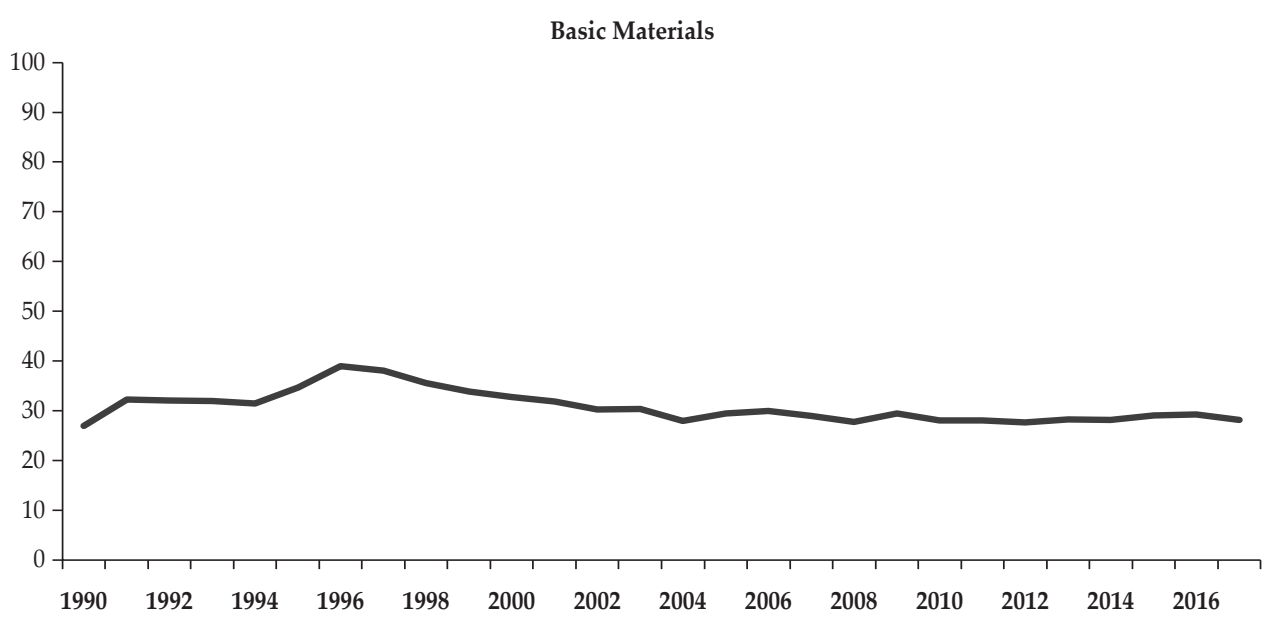

Consumer Goods

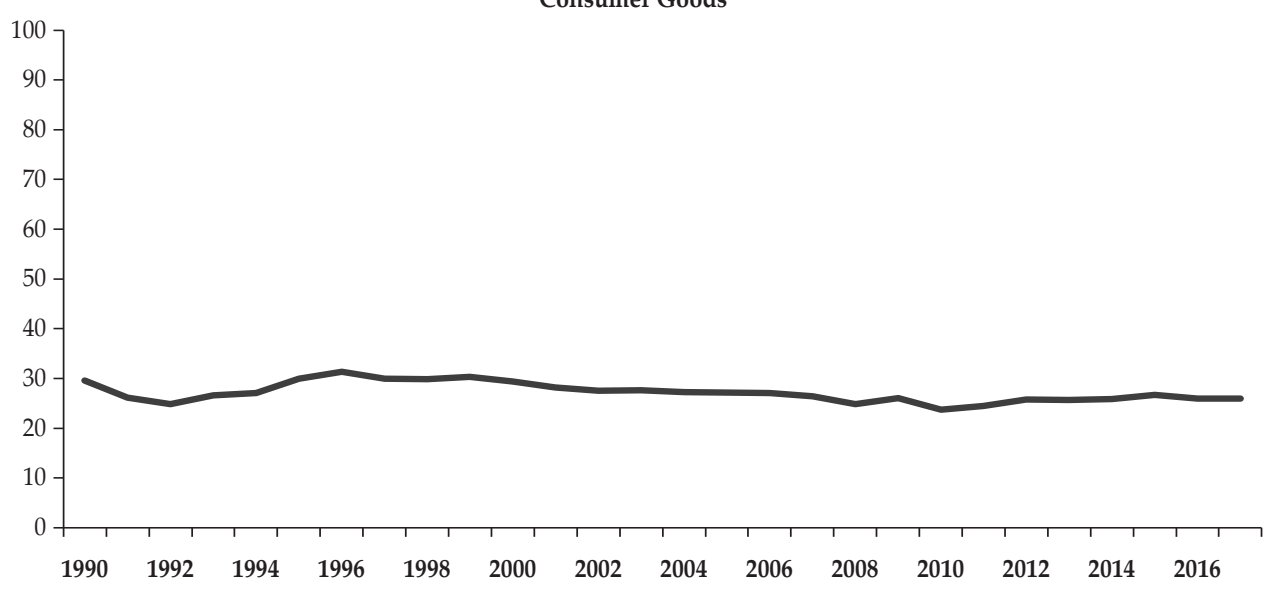


Figure 2.

Trend of Debt Maturity Across Industries (Continued)
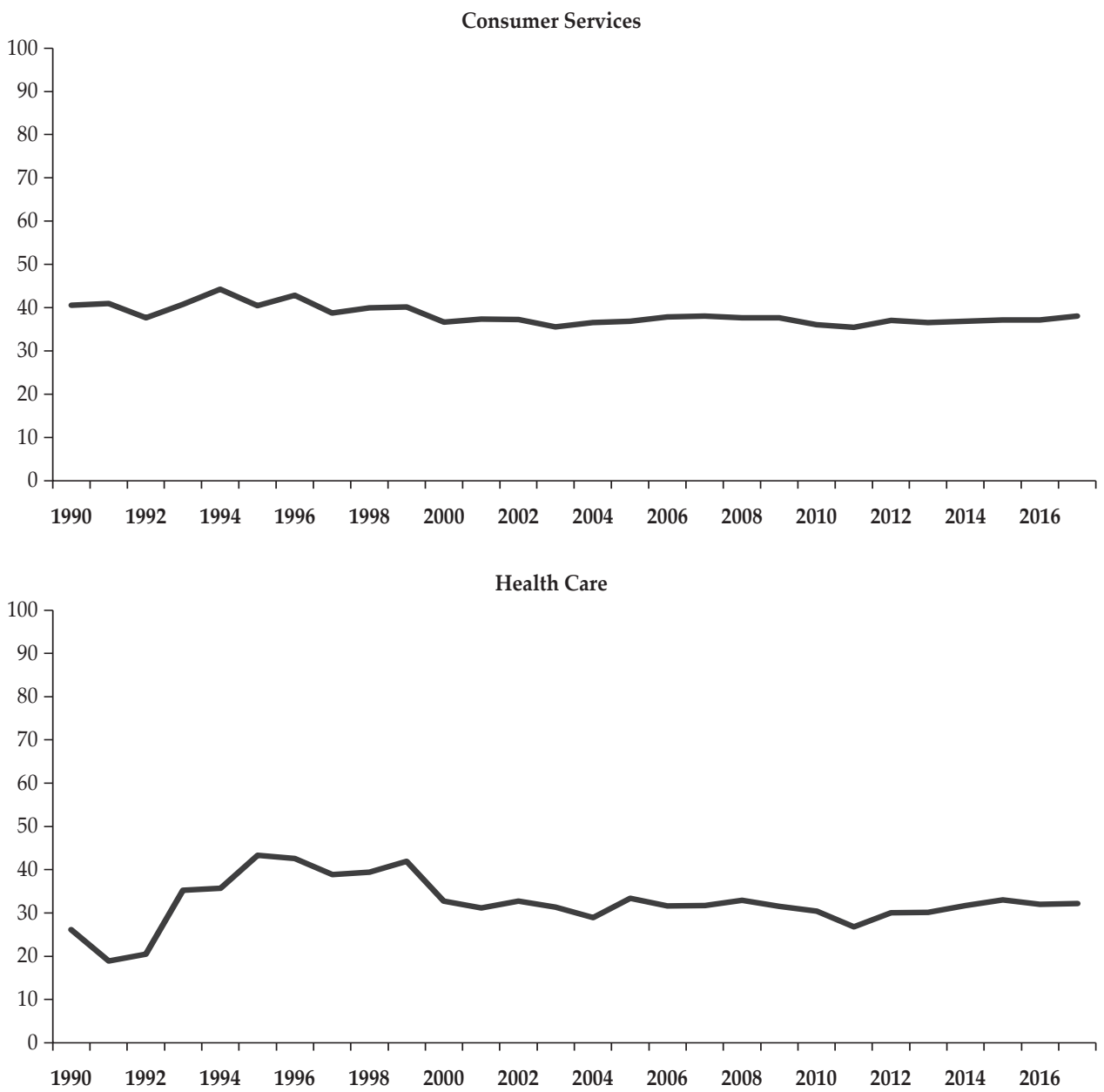

Industrials

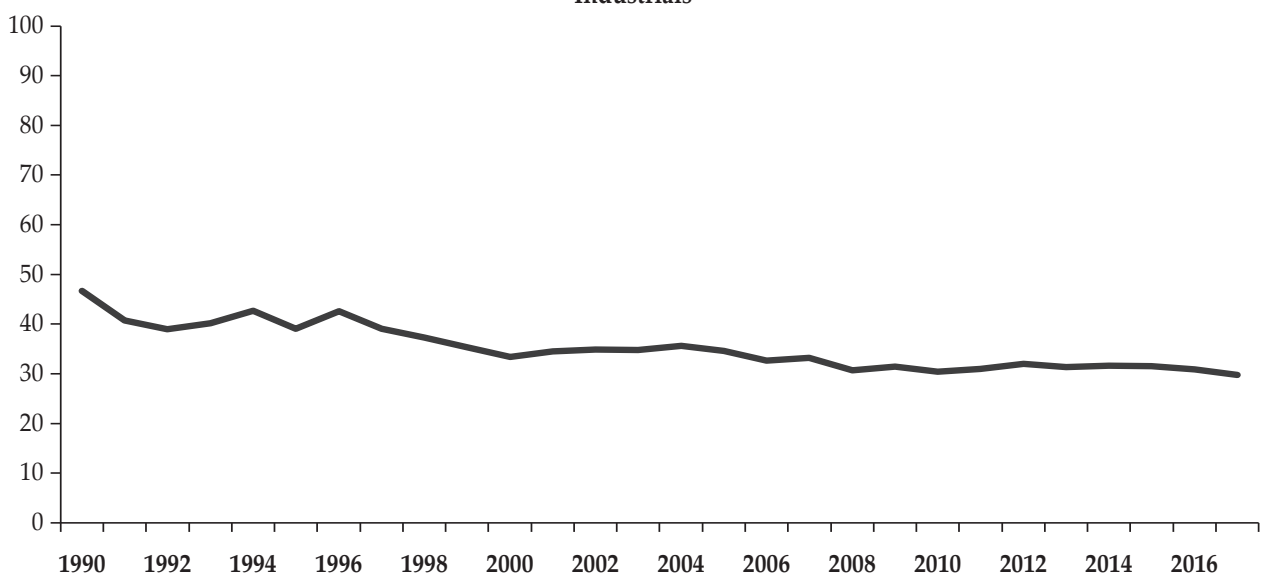


Figure 2.

Trend of Debt Maturity Across Industries (Continued)

Oil \& Gas
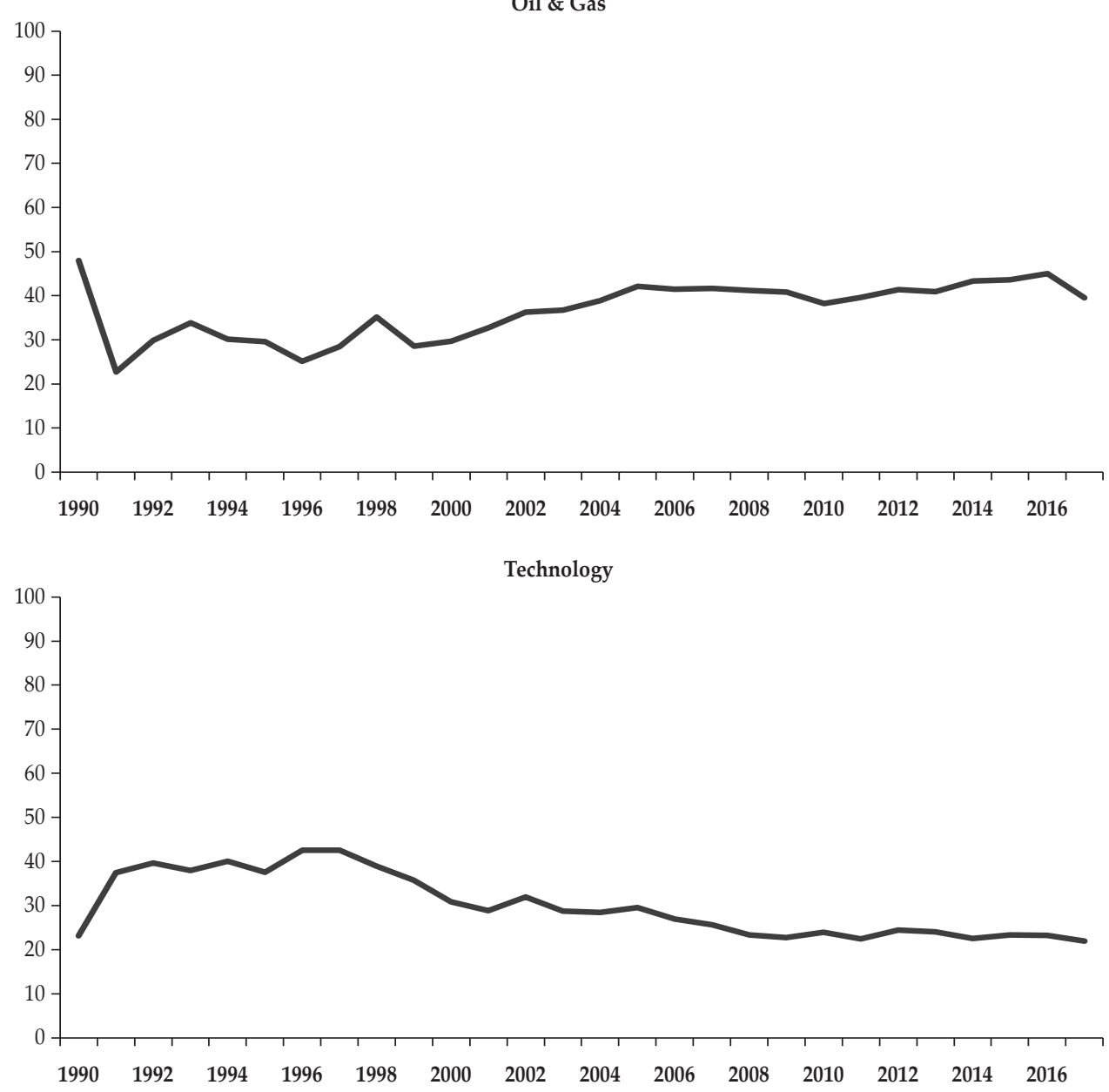

Telecommunication

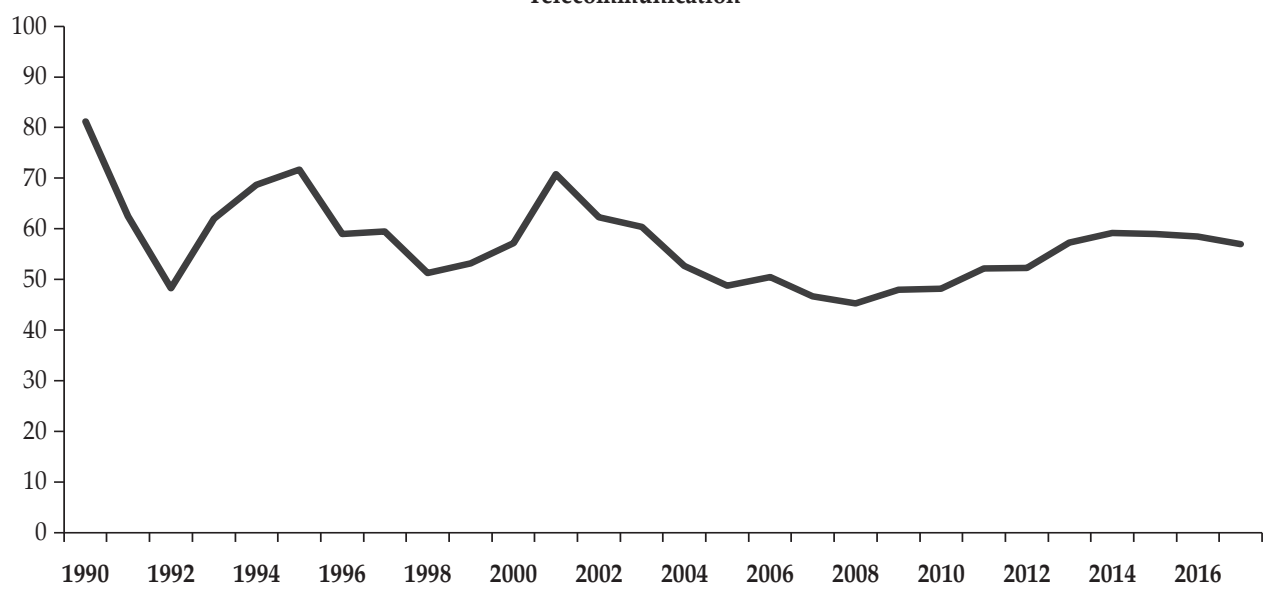


Table 7.

Adjustment Speed of Debt Maturity by Industry

This table shows the adjustment speed of long-term debt - the lagged long-term debt using the LSDVC across eight industries. The dependent variable is long-term debt - DM. Adjusted standard-errors are reported in parentheses (.). Observation numbers are reported italic in brackets [.].** and ${ }^{* *}$ indicate significance at $1 \%$ and $5 \%$, respectively.

\begin{tabular}{|c|c|c|c|c|c|c|c|}
\hline \multirow[b]{2}{*}{ Industry } & \multicolumn{7}{|c|}{ Dependent variable: $D M_{t}$} \\
\hline & $\begin{array}{c}1990- \\
1996\end{array}$ & $\begin{array}{l}1999- \\
2006\end{array}$ & $\begin{array}{l}2010- \\
2017\end{array}$ & Industry & $\begin{array}{c}1990- \\
1996\end{array}$ & $\begin{array}{l}1999- \\
2006\end{array}$ & $\begin{array}{l}2010- \\
2017\end{array}$ \\
\hline \multirow[t]{3}{*}{ Basic Materials } & $0.379^{* * *}$ & $0.503^{* * *}$ & $0.447^{* * *}$ & Industrials & $0.443^{* * *}$ & $0.416^{* * *}$ & $0.468^{* * *}$ \\
\hline & $(0.026)$ & $(0.003)$ & $(0.006)$ & & $(0.038)$ & $(0.000)$ & $(0.017)$ \\
\hline & [486] & {$[2,881]$} & {$[5,519]$} & & [860] & {$[7,047]$} & {$[15,292]$} \\
\hline \multirow[t]{3}{*}{ Consumer Goods } & $0.405^{* * *}$ & $0.466^{* * *}$ & $0.481^{* * *}$ & Oil \& Gas & $0.410^{* * *}$ & $0.469^{* * *}$ & $0.431^{* * *}$ \\
\hline & $(0.024)$ & $(0.013)$ & $(0.000)$ & & $(0.081)$ & $(0.049)$ & $(0.093)$ \\
\hline & [809] & {$[5,393]$} & {$[10,102]$} & & [68] & [403] & {$[1,165]$} \\
\hline \multirow[t]{3}{*}{ Consumer Service } & $0.381^{* * *}$ & $0.409^{* * *}$ & $0.454^{* * *}$ & Technology & $0.526^{* * *}$ & $0.264^{* * *}$ & $0.414^{* * *}$ \\
\hline & $(0.098)$ & $(0.033)$ & $(0.008)$ & & $(0.169)$ & $(0.025)$ & $(0.002)$ \\
\hline & [488] & {$[2,476]$} & {$[4,903]$} & & [110] & {$[2,807]$} & {$[7,571]$} \\
\hline \multirow[t]{3}{*}{ Telecommunication } & $0.989^{* *}$ & $0.285^{* *}$ & $0.433^{* * *}$ & Health Care & $0.716^{* * *}$ & $0.460^{* * *}$ & $0.438^{* * *}$ \\
\hline & $(0.541)$ & $(0.139)$ & $(0.153)$ & & $(0.044)$ & $(0.050)$ & $(0.004)$ \\
\hline & [35] & [230] & [386] & & [84] & [873] & {$[2,216]$} \\
\hline Controls & $\checkmark$ & $\checkmark$ & $\checkmark$ & Controls & $\checkmark$ & $\checkmark$ & $\checkmark$ \\
\hline Firm FE & $\checkmark$ & $\checkmark$ & $\checkmark$ & Firm FE & $\checkmark$ & $\checkmark$ & $\checkmark$ \\
\hline Year FE & $\checkmark$ & $\checkmark$ & $\checkmark$ & Year FE & $\checkmark$ & $\checkmark$ & $\checkmark$ \\
\hline
\end{tabular}

In Table 7, we compare the SOA of long-term debt across eight main industries. First, firms in consumer goods and consumer service industries decrease their SOA of debt maturity over time, and vice versa for health care firms. Next, contrary to industrial, technology and telecommunication firms, basic material and oil \& gas firms decrease and increase their SOA of debt maturity after the AFC and the GFC, respectively. Interestingly, telecommunication firms have the lowest and the highest SOA of debt maturity before and after the AFC, respectively.

In Table 8, we also investigate the SOA of debt maturity across governance level for subperiods. East Asian firms decrease their SOA of debt maturity across the governance level over time. Specifically, firms in high governance countries have faster SOA of debt maturity than those in low governance countries. 
Figure 3.

Trend of Debt Maturity Across Governance Level

This figure presents the trend of debt maturity across governance level from 1990 to 2017 in East Asia.

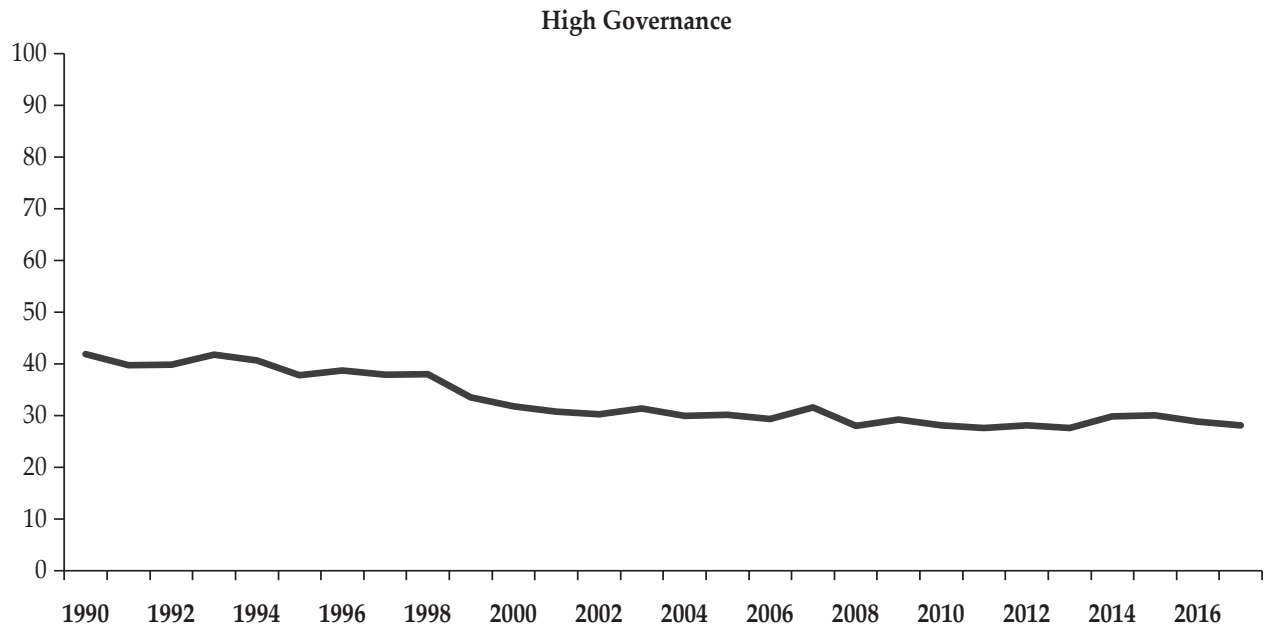

Low Governance

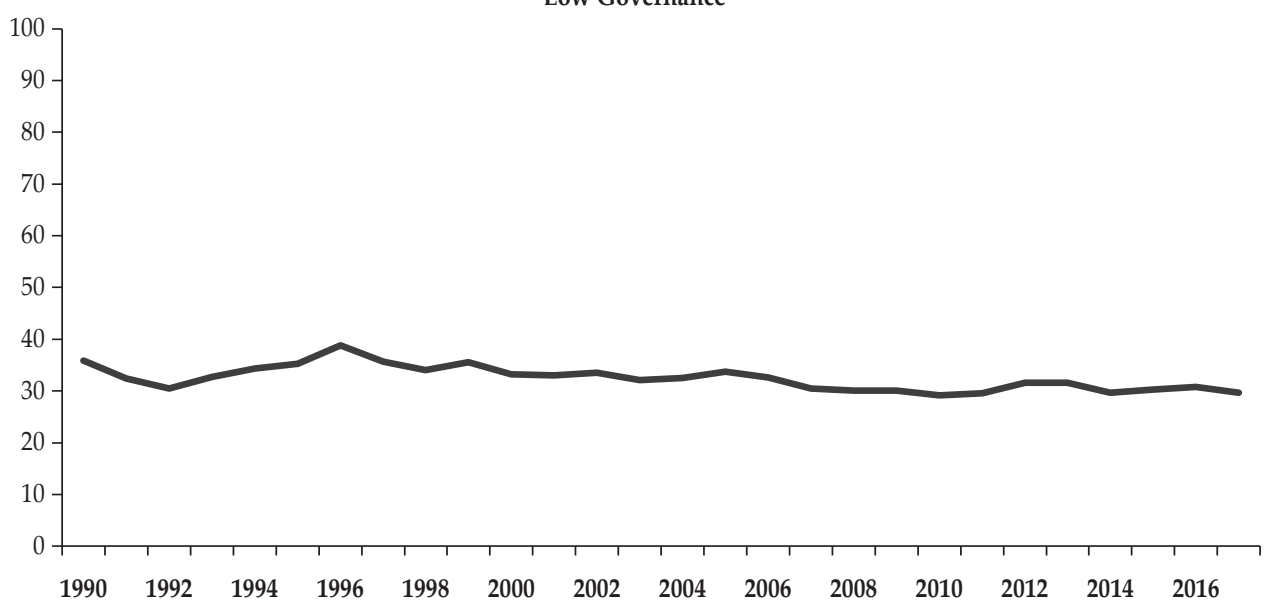

Table 8.

Adjustment Speed of Debt Maturity by Governance Level

This table shows the adjustment speed of long-term debt - the lagged long-term debt using the LSDVC across eight East Asian countries. The dependent variable is long-term debt - DM. Adjusted standard-errors are reported in parentheses (.). Observation numbers are reported italic in brackets [.].*** indicates significance at $1 \%$.

\begin{tabular}{lccccccc}
\hline \multicolumn{7}{c}{ Dependent variable: $D M_{+}$} \\
\hline High GOV & $\mathbf{1 9 9 0 - 1 9 9 6}$ & $\mathbf{1 9 9 9 - 2 0 0 6}$ & $\mathbf{2 0 1 0 - 2 0 1 7}$ & & $\mathbf{1 9 9 0 - 1 9 9 6}$ & $\mathbf{1 9 9 9 - 2 0 0 6}$ & $\mathbf{2 0 1 0 - 2 0 1 7}$ \\
& $0.366^{* * *}$ & $0.391^{* * *}$ & $0.422^{* * *}$ & Low GOV & $0.415^{* * *}$ & $0.435^{* * *}$ & $0.458^{* * *}$ \\
& $(0.035)$ & $(0.041)$ & $(0.001)$ & & $(0.069)$ & $(0.053)$ & $(0.015)$ \\
Controls & {$[987]$} & {$[9,059]$} & {$[19,913]$} & & {$[1,953]$} & {$[15,206]$} & {$[27,241]$} \\
Firm FE & $\checkmark$ & $\checkmark$ & $\checkmark$ & Controls & $\checkmark$ & $\checkmark$ & $\checkmark$ \\
Year FE & $\checkmark$ & $\checkmark$ & $\checkmark$ & Firm FE & $\checkmark$ & $\checkmark$ & $\checkmark$ \\
\hline & $\checkmark$ & $\checkmark$ & $\checkmark$ & Year FE & $\checkmark$ & $\checkmark$ & $\checkmark$ \\
\hline
\end{tabular}




\section{CONCLUSIONS}

We investigate how recent financial crises influence the debt maturity decisions of East Asian firms by examining the optimal long-term debt before and after the financial crises. Employing firms from eight East Asian countries and the LSDVC, we show that optimal debt maturity shortens over the sample period 1990-2017. Specifically, the decrease in adjustment speed of long-term debt after the GFC is more than the decrease after AFC. This is probably due to the shrinkage of credit supply during the global financial crisis being more severe and firms facing bigger costs for borrowing.

This study contributes to the literature in several ways. First, our findings show that East Asian firms decrease their adjustment speed of long-term debt over time. Second, we are the first study to focus on both the GFC and the AFC in the East Asian region and show that two financial crises shorten the optimal debt maturity implying a long-term change in firms maturity structure. Moreover, we find that governance affects optimal debt maturity. These results imply that firms should consider financial crises when they consider their debt maturity policy. Investors also should pay attention to market conditions.

\section{REFERENCES}

Alves, P., \& Francisco, P. (2015). The Impact of Institutional Environment on the Capital Structure of Firms during Recent Financial Crises. The Quarterly Review of Economics and Finance, 57, 129-146.

Arslan-Ayaydin, O., Florackis, C., \& Ozkan, A. (2014). Financial Flexibility, Corporate Investment and Performance: Evidence from Financial Crises. Review of Quantitative Finance and Accounting, 42, 211-250.

Attig, N., Boubakri, N., El Ghoul, S., \& Guedhami, O. (2016). The Global Financial Crisis, Family Control, and Dividend Policy. Financial Management, 45, 291313.

Bae, K. H., \& Goyal, V. K. (2009). Creditor Rights, Enforcement, and Bank Loans. The Journal of Finance, 64, 823-860.

Barnea, A., Haugen, R. A., \& Senbet, L. W. (1980). A Rationale for Debt Maturity Structure and Call Provisions in the Agency Theoretic Framework. The Journal of Finance, 35, 1223-1234.

Blundell, R., \& Bond, S. (1998). Initial Conditions and Moment Restrictions in Dynamic Panel Data Models. Journal of Econometrics, 87, 115-143.

Brick, I. E., \& Liao, R. C., (2017). The Joint Determinants of Cash Holdings and Debt Maturity: The Case for Financial Constraints. Review of Quantitative Finance and Accounting, 48, 597-641.

Campello, M., Graham, J. R., \& Harvey, C. R. (2010). The Real Effects of Financial Constraints: Evidence from a Financial Crisis. Journal of Financial Economics, 97, 470-487.

Coldbeck, B., \& Ozkan, A. (2018). Comparison of Adjustment Speeds in Target Research and Development and Capital Investment: What Did the Financial Crisis of 2007 Change. Journal of Business Research, 84, 1-10.

D'Amato, A. (2020). Capital Structure Debt Maturity and Financial Crisis: Empirical Evidence from SMEs. Small Business Economics, 55, 919-941. 
Dang, T. L., Dang, V. A., Moshirian, F., Nguyen, L., \& Zhang, B. (2019). News Media Coverage and Corporate Leverage Adjustments. Journal of Banking $\mathcal{E}$ Finance, 109, 105666.

Dang, V. A., Kim, M., \& Shin, Y. (2015). In Search of Robust Methods for Dynamic Panel Data Models in Empirical Corporate Finance. Journal of Banking $\mathcal{E}$ Finance, 53, 84-98.

DeAngelo, H., \& Roll, R. (2015). How Stable are Corporate Capital Structures? The Journal of Finance, 70, 373-418.

Demirgüç-Kunt, A., Peria, M. S. M., \& Tressel, T. (2020). The Global Financial Crisis and the Capital Structure of Firms: Was the Impact more Severe among Smes and Non-Listed Firms? Journal of Corporate Finance, 60, 101514.

Duchin, R., Ozbas, O., \& Sensoy, B. A. (2010). Costly External Finance, Corporate Investment, and the Subprime Mortgage Credit Crisis. Journal of Financial Economics, 97, 418-435.

Fan, J. P., Titman, S., \& Twite, G. (2012). An International Comparison of Capital Structure and Debt Maturity Choices. Journal of Financial and quantitative Analysis, 47, 23-56.

Fischer, E. O., Heinkel, R., \& Zechner, J. (1989). Dynamic Capital Structure Choice: Theory and Tests. The Journal of Finance, 44, 19-40.

Flannery, M. J., \& Hankins, K. W. (2013). Estimating Dynamic Panel Models in Corporate Finance. Journal of Corporate Finance, 19, 1-19.

Flannery, M. J., \& Rangan, K. P. (2006). Partial Adjustment Toward Target Capital Structures. Journal of Financial Economics, 79, 469-506.

Freund, R. J., Wilson, W. J., \& Sa, P. (2006). The Analysis of Means. In Altland H.W. Regression Analysis: Statistical Modelling of a Response Variable. 2nd edition, Academic Press: USA 17-26.

Gonzalez, V. M. (2015). The Financial Crisis and Corporate Debt Maturity: The Role of Banking Structure. Journal of Corporate Finance, 35, 310-328.

Gürkaynak, R. S., \& Wright, J. H., (2012). Macroeconomics and the Term Structure. Journal of Economic Literature, 50, 331-67.

Ivashina, V., \& Scharfstein, D. (2010). Bank Lending During the Financial Crisis of 2008. Journal of Financial Economics, 97, 319-338 .

Jensen, M. C., \& Meckling, W. (1976). Theory of The Firm: Managerial Behaviour, Agency Costs, and Capital Structure. Journal of Financial Economics, 3, 305-360.

Kraus, A., \& Litzenberger, R. H. (1973). A State-Preference Model Of Optimal Financial Leverage. The Journal of Finance, 28, 911-922.

Leland, H. E., \& Toft, K. B. (1996). Optimal Capital Structure, Endogenous Bankruptcy, and the Term Structure of Credit Spreads. The Journal of Finance, 51, 987-1019.

Lozano, M. B., \& Yaman, S. (2020). The Determinants of Cash Flow Sensitivity of Cash: The Family Ownership Effect. Research in International Business and Finance, 101204.

Mimouni, K., Temimi, A., Goaied, M., \& Zeitun, R. (2019). The Impact of Liquidity on Debt Maturity After a Financial Crisis: Evidence from the Gulf Cooperation Council Region. Emerging Markets Finance and Trade, 55, 181-200.

Modigliani, F., \& Miller, M. H. (1958). The Cost of Capital, Corporate Finance and Theory of Investment. The American Economic Review, 48, 261-97. 
Myers, S. C. (1977). Determinants of Corporate Borrowing. Journal of Financial Economics, 5, 147-175.

Ozkan, A. (2000). An Empirical Analysis of Corporate Debt Maturity Structure. European Financial Management, 6, 197-212.

Ozkan, A. (2002). The Determinants of Corporate Debt Maturity: Evidence from UK Firms. Applied Financial Economics, 12, 19-24.

Sawicki, J. (2009). Corporate Governance and Dividend Policy in Southeast Asia Pre-And Post-Crisis. The European Journal of Finance, 15, 211-230.

Song, K., \& Lee, Y. (2012). Long-Term Effects of a Financial Crisis: Evidence from Cash Holdings of East Asian Firms. Journal of Financial and Quantitative Analysis, 617-641.

Tekin, H. (2020a). How Optimal Cash Changed by the Global Financial Crisis? A Multi-Country Analysis. Economics and Business Letters, 9, 114-123.

Tekin, H. (2020b). Market Differences and Adjustment Speed of Debt, Equity, and Debt Maturity. Australian Journal of Management. https://doi.org/10.1177/0312896220968266

Tekin, H., \& Polat, A. Y. (2020a). Is Saving Vital? Evidence from the Financial Crisis. Economics and Business Letters, 9, 124-134.

Tekin, H., \& Polat, A. Y. (2020b). Do Market Differences Matter on Dividend Policy? Borsa Istanbul Review. https://doi.org/10.1016/j.bir.2020.10.009

Tsoy, L., \& Heshmati, A. (2019). Impact of Financial Crises on the Dynamics of Capital Structure: Evidence from Korean Listed Companies. The Singapore Economic Review, 1950049.

Turk-Ariss, R. (2016). Legal Systems, Capital Structure, and Debt Maturity in Developing Countries. Corporate Governance: An International Review, 24, 130144.

Van Hoang, T. H., Gurău, C., Lahiani, A., \& Seran, T. L. (2018). Do Crises Impact Capital Structure? a Study of French Micro-Enterprises. Small Business Economics, 50, 181-199.

Vermoesen, V., Deloof, M., \& Laveren, E. (2013). Long-Term Debt Maturity and Financing Constraints of SMEs during the Global Financial Crisis. Small Business Economics, 41, 433-448.

Zeitun, R., Temimi, A., \& Mimouni, K. (2017). Do Financial Crises Alter the Dynamics of Corporate Capital Structure? Evidence from GCC Countries. The Quarterly Review of Economics and Finance, 63, 21-33. 
This page is intentionally left blank 